\title{
Factors influencing e-commerce development: Implications for the developing countries
}

\author{
Christian Mbayo Kabango, Asa Romeo Asa \\ School of Management Science, Wuhan University of Technology, China
}

\begin{abstract}
The rapid growth of E-Commerce initiatives in the world reflects its compelling advantages, such as enhanced governmental performance, lower cost structure, greater flexibility, broader scale and scope of services, greater transparency, accountability, and faster transactions. This study aims to determine the connection and effects that attitudes have on e-commerce is paramount to developing ecommerce. In developing countries, IT and communication or rather e-commerce growth are substantial. Technology effectiveness is essential in E-Commerce success. However, human, economic, and other organizational issues must be taken into account as well. In this study, we evaluated the current status of E-Commerce in developing countries. The evaluation of current status reveals opportunities that should be seriously tackled by organizations, if they are to survive the consequences of globalization and open markets. There should be an immediate implementation of a governmental infrastructure to support e-commerce.
\end{abstract}

Keywords: E-commerce development, customer trust, internet privacy

\section{INTRODUCTION}

The availability and continued growth of Internet technologies (IT) have created great opportunities for users all over the globe to benefit from IT services and use them in a variety of different ways. The use of IT to conduct business online is known as Electronic Commerce (E-Commerce).

We are witnessing a boom of new technologies, especially in the service sector (IT, Telecommunications, Internet, etc.). Due to technological advances economic transactions have become much easier and faster and this is mainly because of the development of e-commerce. Real engine of the new economy, e-commerce is a remarkable source of competitive advantage for businesses and a new space for consumers. In the coming years, growth and profitability will depend most likely the ability to introduce these new emerging technologies and adopt new methods of business transactions. Since many years ago computers, appliances, plane tickets and many other items are available for purchase on the Internet using cards issued by local banks. Although this technological trend could significantly strengthen the national economic structure, its role and place in developing countries economic structure remains unclear and leaves many questions to ask:

Where is the e-commerce today?

What are the obstacles to e-commerce? Is e-commerce having a bright future to become a mainstream business for growth, and what steps to take to get there?

While developed countries have harnessed and adopted E-Commerce, developing countries are not yet fully adapted to its adoption. The aim of this study is to investigate the factors that play a role in the adoption and development of E-Commerce and, hence, develop strategies that conceptualize the 


\section{Christian Mbayo Kabango, Asa Romeo Asa \\ Factors influencing e-commerce development: implications for the developing countries}

influential factors that form as enablers and disablers of E-Commerce. In this paper we provide some answers about the current situation of e-commerce think later on prospects that will enable the benefits from all the advantages offered by this new mode of trade. This paper is organized as follows. Firstly, a concept of e-commerce is briefly introduced, followed by the construction of the research model, including all the aspects of e-commerce that are the object of our investigation. Finally, implications drawn on the study results and analysis are discussed, followed by the research limitations and a conclusion.

\section{UNDERSTANDING THE CONCEPT OF E-COMMERCE}

Information and communication technology (ICT) is radically transforming the way individuals, organizations, and governments work. The internet in today's information societies has become an essential channel that is used for dissemination of information, products, and services. People prefer to use the internet as a transaction tool in different areas, such as, learning, shopping, marketing, travel, trading, etc. Carter and Belanger (2003) emphasized the use of ICT to improve efficiency and access to government services across all stakeholders in G2C, G2E, G2G and G2B services. Additionally, governments have realized the importance of the internet and have undertaken critical transformations to use it to deliver public services, so that citizens can always access them regardless of their location (Abdulkarim, 2003). Fang (2002) has described e-government (part of e-commerce) as a method for governments to use the most innovative ICT services, particularly web-based internet applications. These applications are able to provide citizens and businesses with more convenient access to government information and services, to improve the quality of services and provide more opportunities for democratic institutions and processes. E-Commerce involves many issues such as trust, security, privacy, accessibility, familiarity, awareness, and quality of public services (Jaeger, 2003). For instance, the rapid growth of E-Commerce initiatives in the MENA (Middle East and North Africa) region reflects its compelling advantages, such as enhanced governmental performance, lower cost structure, greater flexibility, broader scale and scope of services, greater transparency, accountability, and faster transactions. However, getting people to be continually engaged in e-commerce services is a challenge since only with a few mouse clicks they will be moved away. An agreement seems to enhance better customer service and its consequent effect on online satisfaction and reuse. Especially, online satisfaction is not the only primary driver of online customers' continuous behavior, but also the key to building and retaining a loyal base of long-term customers. Many institutions, such as the World Bank, the United Nations, Europe's Information Society DG, the Canadian Common Measurement Tool (CMT) of satisfaction, the European Customer Satisfaction Index and the American Customer Satisfaction Index, evaluate e-commerce progress and satisfaction using various methods and indices (Fitsilis, Anthopoulos, \& Gerogiannis, 2010).

Businesses implementing E-Commerce in developing countries face substantially greater challenges than businesses in developed countries due to the unreliability of the internet connection, the poor availability of accessing it due to the poor infrastructure, the high cost of doing so, and also the low level of ICT penetration throughout the country (Molla and Licker, 2005b; Molla and Licker, 2005a). Aleid (2009) carried out an investigation of different E-Commerce schemes in a number of countries with regard to culture, infrastructure and human behavior. They find that there are a number of factors that may inhibit the diffusion of E-Commerce into developing countries (e.g. infrastructure, security, E-Commerce laws). This study will focus on Developing countries, which is considered to be a marketplace, which is booming for E-Commerce activities in the Middle East (Eid, 2011). Developing countries require further Internet access, exploring opportunities for the Internet in education, government and commerce. However, for these things to be achieved certain requirements need to exist where certain factors play an important role. Next we discuss the most essential factors for the development and effectiveness of e-commerce. 


\section{KEY FACTORS IMPACTING ECOMMERCE}

\section{TRUST}

Johnson-George and Swap (1982: 1306) asserted that "willingness to take risks may be one of the few characteristics common to all trust situations." Kee and Knox (1970) argued that to appropriately study trust there must be some meaningful incentives at stake and that the trustor must be cognizant of the risk involved. The definition of trust proposed in this research is the willingness of a party to be vulnerable to the actions of another party based on the expectation that the other will perform a particular action important to the trustor, irrespective of the ability to monitor or control that other party (Park and Kim, 2003). Trust can be a vital factor in business to consumer (B2C) E-Commerce. It gives consumers faith to buy products or services even if an e-trader is unknown. It encourages more use of E-Commerce technologies, makes the e-transaction process easier, enhances the level of acceptance and adoption of E-Commerce, leads to the improvement of consumer commitment, raise customer satisfaction, introduces the concept of loyalty, sustains long-term relationships with customers and assists the acquiring of a competitive benefit. Future purchases can be motivated and increased prices tolerated. It reduces customer worries about information privacy, and helps customers to tolerate the irregular mistakes made by the e-trader (Pittayachawan, 2008). Trust is a complicated concept and has a multitude of sides to be addressed. There are a number of researchers who have continually approached the 'trust' issue from a technical side such as Internet and network security and even web interface design (Fernandes, 2001; Clifford et al., 1998; Pittayachawan, 2008). Nonetheless, according to Klang (2001) and Ratnasingham and Kumar (2000), considering just the technical perceptions will not guarantee trust in e-commerce.

\section{SECURITY, FRAUD AND HACKING}

It is widely acknowledged by both government and industrial organizations that, from a consumer point of view, issues of information security are a major obstacle to the growth of E-Commerce. The perception of risk regarding Internet security has also been recognized as a concern for both experienced and inexperienced users of Internet technologies (Miyazaki and Fernandez, 2001). Furthermore, Miyazaki and Fernandez (2001) have identified the fraudulent behavior by online retailers as a key concern for Internet users and, therefore, E-Commerce users Rose et al. (1999) identifies hackers as an obvious security threat to E-Commerce.

This happens because the online availability and accessibility of the stored data of many corporations gives any hacker on the Internet the chance to steal data from these corporate databases. These threats have been identified in several new studies (Aleid et al., 2009; Al-Ghaith et al., 2010). Dixit and Datta (2010) studied the acceptance of e-banking among adult customers in India. The findings depicted that many factors like security and privacy, trust, innovativeness, familiarity, and awareness level increase the acceptance of e-banking services among Indian customers.

\section{AWARENESS AND PERCEIVED USEFULNESS}

Within the context of the information systems (IS) domain, much research has outlined the significance of the influence of perceived usefulness on attitude towards the use of e-commerce.

The real reason why customers would use E-Commerce is that they find it a useful facility for conducting shopping online (Alghamdi, 2011). Furthermore, according to Sathye's (1999) research, the use of online banking services, which is a good example of e-commerce, is new knowledge to many customers, and the lack of awareness of online banking is a crucial factor in preventing customers from adopting it. In his study of 500 Australian customers, he concluded that customers were not aware of the potential benefits of online banking. This was supported by another study by Howcroft et al., (2002) in which they 


\section{Christian Mbayo Kabango, Asa Romeo Asa \\ Factors influencing e-commerce development: implications for the developing countries}

found that the issue of lack of awareness and knowledge of online banking services contributes ecommerce adoption challenges. Suki and Ramayah (2010) studied user acceptance of the e-Government services in Malaysia. Their results indicate that the important determinants of user acceptance of the eGovernment services are perceived usefulness, ease of use, compatibility, interpersonal influence, external influence, self-efficacy, facilitating conditions, attitude, subjective norms, perceived behavioral control, and intention to use e-Government services/system.

\section{ACCESSIBILITY}

As the internet is fast becoming a major source of information and services, a well-designed e-commerce website has become essential so that citizens can access public information and improve their participation. E-commerce websites can serve as a tool for both communication and relations for the customers and general public. Information and data can easily be shared with and transferred to external stakeholder (Moon, 2002). Henry (2006) defines web accessibility as getting people to use, perceive, understand, direct and interact with the web. The International Standards Organizations (ISO) has defined accessibility as "the usability of a product, service, environment or facility by people with the widest range of capabilities".

Gummerus et al. (2004) define the user interface as the channel through which customers are in contact with the e-service provider. Park and Kim (2003) found that the quality of the user interface affects customer satisfaction directly, since it provides physical evidence of the service provider's competence as well as facilitating effortless use of the service. Because of its importance to customer satisfaction, Tan, Tung, and $\mathrm{Xu}$ (2009) identified fourteen key factors for developing effective B2C e-commerce websites. Also, Cyr (2008) investigated the effect of B2C e-commerce website user interface design factors (such as information design, navigation design, and visual design) on trust and satisfaction across three developed countries; Canada, Germany, and China. Cyr found that these user interface design variables are key antecedents to website trust and website satisfaction across cultures.

\section{PERCEIVED QUALITY}

The perceived quality of a service has two dimensions; the technological dimension, which refers to what is delivered, and the functional dimension, which refers to how the service is delivered. Speed of response, offer updates, and site effectiveness, refers to the technical quality (Rust \& Lemon, 2009). Interactive communication, personalization of the communication and of the service, as well as new forms of customer access refers to the functional aspect of quality. Product/service quality is defined as the customer perception of the quality of information about the product/service that is provided by a website (Park \& Kim, 2003). According to Mcknight etal., 2002, website content quality has been argued to be an antecedent of online customer trust on quality. In addition, Park and Kim (2003) found that the information quality affects customer satisfaction directly. Karunasena and Deng (2012) have identified the critical factors for evaluating the public value of e-Government in Sri Lanka. The study showed that the deliveries of quality information and services, user-orientation of information and services, efficiency and responsiveness of public organizations and contributions of public organizations to the environmental sustainability are the critical factors for evaluating the public value of e-Government in Sri Lanka.

\section{ROLE OF GOVERNMENT}

The government's role in developing countries as an important one that facilitates the essential requirements for the development of E-Commerce such as providing robust secure online payment options, ensuring a solid ICT infrastructure, providing educational programs and building up awareness using different means such as media and education institutions. The results of their study show the significance of government promotion and support as a crucial factor (AlGhamdi et al., 2011). According to Molla and Licker (2005), state that the government demonstrates strong commitment to promoting E- 
Commerce. In Saudi Arabia, Eid (2011) posit in his study that the Saudi Government's support was recognized as an important element in the development and growth of local E-Commerce. According to Eid's study, some Saudi citizens believe in the importance of the government's role. Interviewee 8 commented on the diffusion of E-Commerce by government and private accreditation in providing the basic facilities such as a house address for every citizen, to be used online for accurate delivery of products and documents and special services. If there is no reliable postal service, there will be no egovernment.

\section{CONSTRUCTING A RESEARCH MODEL}

The development of E-Commerce in this research is measured along the four facets stipulated in the diagram below. This study allows the researcher to discover general attitudes and perception that people have on personal, technological and transactional levels. To determine the connection and effects these attitudes have on e-commerce is paramount to developing e-commerce. The facets surrounding this study revolve on the following;

Security and privacy: the perception of e-commerce portals as secure platforms without any uncertainty and adverse consequences after e-commerce use, and the ability to determine when and what extent information about them is communicated to others for maintaining confidentiality.

Trust and Loyalty: the willingness of people to rely on and willingness to frequently use e-commerce portals for conducting transactions based on the feelings of confidence and assurance.

Accessibility and Awareness: the perception of user interface quality and the degree of awareness on information about products and services delivered from conducting transactions from any location at any time through e-commerce portals.

Quality and benefits: the perception of quality of products and services offered from e-commerce portals and benefits that arose from conducting such transactions.

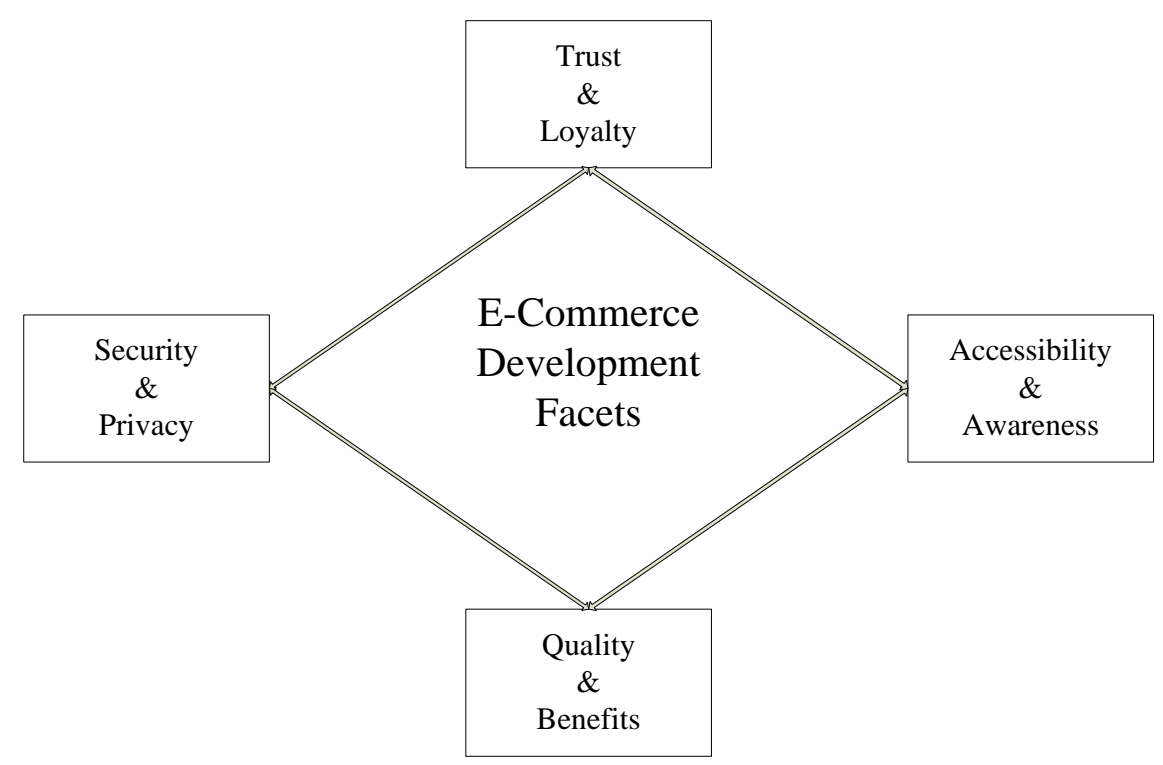

FIGURE 1: The Research Model 


\section{IMPLICATIONS FOR ECOMMERCE IN DEVELOPING COUNTRIES}

In developing countries, IT and communication or rather e-commerce growth are substantial. Technology effectiveness is essential in E-Commerce success. However, human, economic, and other organizational issues must be taken into account as well. In this study, we evaluated the current status of E-Commerce in Developing countries. The evaluation of current status reveals opportunities that should be seriously tackled by organizations, if they are to survive the consequences of globalization and open markets. There should be an immediate implementation of a governmental infrastructure to support e-commerce. This thesis explored the areas enabling and huddles to the development of e-commerce. Online consumers face problems concerning security and privacy. They are exposed with online risk such as hacker mischiefs. Moreover, when buyers make payment using credit cards, they are exposing their banking information which could also be manipulated by hackers. The results of this research showed that majority of the respondents felt that internet shopping is risky due to the same reason. Amongst the perceived risks is financial, product performance, social, psychological and time convenience loss. Other than stolen credit card information, there are also risks in delivery. The time taken for delivery may take quite some time, therefore, anything could happen in the process of delivery. Buyers may lose the item. Online vendors might not be responsible for the loss and this leaves the buyers to bear all the consequence. When the perceived risk is greater, the relationship between intention and online purchasing will be weakened.

The implementation of an effective Internet e-commerce solution in Developing countries or other country that want to develop its e-commerce system can consider the following key steps: Developing strategy; before implementing Internet e-commerce, an organization must clearly define its goals. Many companies create goals that are not measurable or specific. Assessing readiness; before taking on the complexities (and risks) associated with implementing Internet e-commerce, an organization and its management should take stock of their current systems and capabilities. Four key drivers predict an enterprise's ability to succeed in e-commerce. These four drivers are: leadership; governance; competencies; and technology.Designing the project; Although projects will differ greatly in the details, there are some common requirements for implementing Internet e-commerce, including: managing the project, developing an outsourcing strategy, selecting an Internet service provider, selecting e-commerce service providers; and designing website security. Integrating the solution; In developing an Internet ecommerce platform, an organization must also consider how to integrate its e-commerce applications with its other business processes. For example, the richness of corporate intranet applications positively affects e-commerce capabilities. Extending intranet applications into the Internet permits an organization to provide more value to customers in several ways: real-time access to information; and ability to perform business transactions. Measuring effectiveness: Given the major investment that implementing e-commerce entails, it is only common sense to measure the return. Successful e-commerce companies have serious and accountable metrics and clear agreements about using them across the organization. It is in the appropriateness and completeness of the metrics selected that typically set successful ecommerce implementations apart from the ones that are unsuccessful.

\section{CONCLUSION}

Under the guidance of grounded theory and through analyzing and synthesizing the gathered data, a content analysis of e-commerce enablers and disablers in developing countries was constructed.

This research highlights the most important factors that need to be considered in order to support the proliferation and advancement of e-commerce. Countries need to encourage and improve the ecommerce developments. This research sheds light on the potential factors that may play a significant role in supporting the proliferation and advancement of E-Commerce in developing countries. The outcomes of this study may contribute to the market stakeholders' understanding of their potential customers' needs and current concerns. Exploring the market, especially at this time while e-commerce is still in its development stage, is critical for industry stakeholders in order to ensure the success of this 


\section{Christian Mbayo Kabango, Asa Romeo Asa \\ Factors influencing e-commerce development: implications for the developing countries}

emerging market. Future research should focus on studying the development of e-commerce and testing the research model. Consequently, potentially important dimensions of the study could include an investigation in multiple cities, and especially in more rural areas, which may lead to more accurate and comprehensive results and analysis. Also, comparative research in different parts of the world would produce more complete findings. The results of this study could then be compared with those of other developing countries having similar conditions to see if there is a significant difference.

\section{REFERENCES}

- Al-Ghaith, W. A., Sanzogni, L., \& Sandhu, K. (2010). Factors influencing the adoption and usage of online services in Saudi Arabia. The Electronic Journal of Information Systems in Developing Countries, 40.AlGhamdi, Rayed, Steve Drew, and Osama AlFaraj. "Issues influencing Saudi customers' decisions to purchase from online retailers in the KSA: a qualitative analysis." European Journal of Scientific Research 55.4 (2011): 580-593.

- Alqahtani, M. A., Al-Badi, A. H., \& Mayhew, P. J. (2013). Exploratory Study of M-Transaction: User's Perspectives. The Electronic Journal of Information Systems in Developing Countries, 60.Anthopoulos, Leonidas G., Vassilis C. Gerogiannis, and Panos Fitsilis. "Measuring eGovernment adoption by governments: the Greek case."Comparative E-Government. Springer New York, 2010. 353-370.

- Bailey, C. J., Mynett, K. J., \& Page, T. (1994). Importance of the intestine as a site of metformin - stimulated glucose utilization. British journal of pharmacology, 112(2), 671-675.

- Carter, L., \& Belanger, F. (2003). Diffusion of innovation \& citizen adoption of e-government. In The Fifth International Conference on Electronic Commerce (pp. 57-63).

- Cyr, D. (2008). Modeling web site design across cultures: relationships to trust, satisfaction, and e-loyalty. Journal of Management Information Systems, 24(4), 47-72.

- Dixit, N., \& Datta, S. K. (2010). Acceptance of E-banking among Adult Customers: An Empirical Investigation in India. Journal of Internet Banking \& Commerce, 15(2).

- Eid, M. I. (2011). Determinants of e-commerce customer satisfaction, trust, and loyalty in Saudi Arabia. Journal of Electronic Commerce Research, 12(1), 78-93.

- Fang, Z. (2002). E-government in digital era: concept, practice, and development. International journal of the Computer, the Internet and management, 10(2), 1-22.

- Gummerus, J., Liljander, V., Pura, M., \& Van Riel, A. (2004). Customer loyalty to content-based web sites: the case of an online health-care service. Journal of services Marketing, 18(3), 175186.

- Harrison McKnight, D., Choudhury, V., \& Kacmar, C. (2002). The impact of initial consumer trust on intentions to transact with a web site: a trust building model. The Journal of Strategic Information Systems, 11(3), 297-323.

- Henry, S. L. (2006). Introduction to Web accessibility. Retrieved April, 9.

- Howcroft, B., Hamilton, R., \& Hewer, P. (2002). Consumer attitude and the usage and adoption of home-based banking in the United Kingdom. International journal of bank marketing, 20(3), 111-121.

- Jaeger, P. T. (2003). The endless wire: E-government as global phenomenon. Government Information Quarterly, 20(4), 323-331.

- Johnson-George, C., \& Swap, W. C. (1982). Measurement of specific interpersonal trust: Construction and validation of a scale to assess trust in a specific other. Journal of Personality and Social Psychology, 43(6), 1306.

- Karunasena, K., \& Deng, H. (2012). Critical factors for evaluating the public value of egovernment in Sri Lanka. Government Information Quarterly, 29(1), 76-84.

- Kee, H. W., \& Knox, R. E. (1970). Conceptual and methodological considerations in the study of trust and suspicion. Journal of Conflict Resolution.

- Kessens, A. B. Zorgen voor ieder kind.

- Klang, M. (2001). Who do you trust? Beyond encryption, secure e-business. Decision Support Systems, 31(3), 293-301.

- Lynch, C. (1998). A White Paper on the Authentication and Access Management Issues in Crossorganizational Use of Networked Information Resources. Educause. 
- Miyazaki, A. D., \& Fernandez, A. (2001). Consumer perceptions of privacy and security risks for online shopping. Journal of Consumer Affairs, 35(1), 27-44.

- Miyazaki, A. D., \& Fernandez, A. (2000). Internet privacy and security: An examination of online retailer disclosures. Journal of Public Policy \& Marketing, 19(1), 54-61.

- Molla, A., \& Licker, P. S. (2005). eCommerce adoption in developing countries: a model and instrument. Information \& Management, 42(6), 877-899.

- Molla, A., \& Licker, P. S. (2005). Perceived e-readiness factors in e-commerce adoption: an empirical investigation in a developing country. International Journal of Electronic Commerce, $10(1), 83-110$.

- Moon, M. J. (2002). The Evolution of E - Government among Municipalities: Rhetoric or Reality?. Public administration review, 62(4), 424-433.

- Park, C. H., \& Kim, Y. G. (2003). Identifying key factors affecting consumer purchase behavior in an online shopping context. International Journal of Retail \& Distribution Management, 31(1), 16-29.

- Pittayachawan, S., Singh, M., \& Corbitt, B. (2008). A multitheoretical approach for solving trust problems in B2C e-commerce. International Journal of Networking and Virtual Organisations, 5(3), 369-395.

- Ratnasingham, P., \& Kumar, K. (2000, December). Trading partner trust in electronic commerce participation. In Proceedings of the twenty first international conference on Information systems (pp. 544-552). Association for Information Systems.

- Roscoe, J. T. (1974). Fundamental research statistics for the behavioral sciences. Holt, Rinehart and Winston.

- Rose, G., Khoo, H., \& Straub, D. W. (1999). Current technological impediments to business-toconsumer electronic commerce. Communications of the AIS, 1(5es), 1.

- Sait, S., Al-Tawil, K., \& Hussain, S. (2007). E-commerce in Saudi Arabia: Adoption and perspectives. Australasian Journal of Information Systems, 12(1).

- Sathye, M. (1999). Adoption of internet banking by Australian consumers: an empirical investigation. International Journal of bank marketing, 17(7), 324-334.

- Suki, N. M., \& Ramayah, T. (2010). User Acceptance of the E-Government Services in Malaysia: Structural Equation Modelling Approach. Interdisciplinary Journal of Information, Knowledge \& Management, 5.

- Tan, F. B., Tung, L. L., \& Xu, Y. (2009). A Study of Web-designer's Criteria for Effective Business-to-consumer (B2C) Websites Using the Repertory Grid Technique. Journal of Electronic Commerce Research, 10(3).

- Verhoef, P. C., Lemon, K. N., Parasuraman, A., Roggeveen, A., Tsiros, M., \& Schlesinger, L. A. (2009). Customer experience creation: Determinants, dynamics and management strategies. Journal of Retailing, 85(1), 31-41. 